\title{
Charakterystyka polskiej diaspory w Kurytybie (Brazylia) w świetle badań społecznych \\ Characteristics of the Polish diaspora in Curitiba (Brazil) in the light of social research
}

\author{
Karel Dolinski $\odot$ Magdalena Szmytkowska $\odot$ \\ Uniwersytet Gdański, Katedra Geografii Społeczno-Ekonomicznej \\ ul. Bażyńskiego 4, 80-309 Gdańsk \\ karel.dolinski@phdstud.ug.edu.pl•geoms@univ.gda.pl
}

Zarys treści. W prezentowanym artykule podjęto temat współczesnej polskiej diaspory zamieszkującej w Kurytybie, mieście ważnym i symbolicznym z punktu widzenia kształtowania się migracji Polaków do Brazylii od drugiej połowy XIX w. Jako tło głównych rozważań przedstawiono ogólny zarys historii migracji Polaków do Kurytyby, a także omówiono i uzasadniono znaczenie Kurytyby jako szczególnej przestrzeni obecności i aktywności społecznej diaspory polskiej w Brazylii. Zasadniczą część opracowania stanowi opis członków polskiej diaspory w aspekcie demograficzno-społecznym, a także określenie poczucia polskości i związków z krajem pochodzenia przodków na podstawie badań ankietowych na celowej grupie respondentów.

Słowa kluczowe: migracje zagraniczne, diaspora polska, Brazylia, Kurytyba, badania społeczne.

\section{Wstęp}

Kurytyba jest miastem, którego kolejne fazy rozwojowe, wiązały się bezpośrednio z żywiołowymi falami migracyjnymi. Podstawowym impulsem rozwojowym, który zdecydował o ukształtowaniu się funkcji miejskich, był wzmożony napływ emigrantów, głównie z Europy, w drugiej połowie XIX w. (Rabinovitch, 1992). Według danych spisowych z 1872 r. miasto zamieszkiwało wówczas zaledwie około 12,6 tys. mieszkańców. Rozwój funkcji miejskich w drugiej połowie XIX w. pokrywa się z wydarzeniem wydzielenia Prowincji Parana (obecnie stan Parana) z Prowincji Sao Paulo w dniu 20 sierpnia 1853 r. (Garcez, 2006). Do wybuchu I wojny światowej zanotowano jeszcze dwie duże fale migracyjne (w latach 1890-1896 i 1907-1914), szacowane łącznie na 55 tys. osób. W 1920 r. miasto zamieszkiwało 80 tysięcy mieszkańców, a w 1940 r. - już 140 tys. osób (Wójtowicz, 2014). Największy rozwój gospodarczy, a wraz z nim żywiołowy rozwój demograficzny rozpoczął się jednak w latach 50. XX w., o czym świadczy fakt, że w trzech kolejnych dekadach następowało podwajanie liczby ludności (ryc. 1). Trend ten był analogiczny do sytuacji w całym kraju. Dynamiczny rozwój urbanizacji, wynikający z realizacji polityki intensywnej industrializacji miast, był wzmacniany dokonującą się modernizacją rolnictwa na obszarach wiejskich, co wywołało gwałtowną i wielką falę migracji wewnętrznych ze wsi do miast 


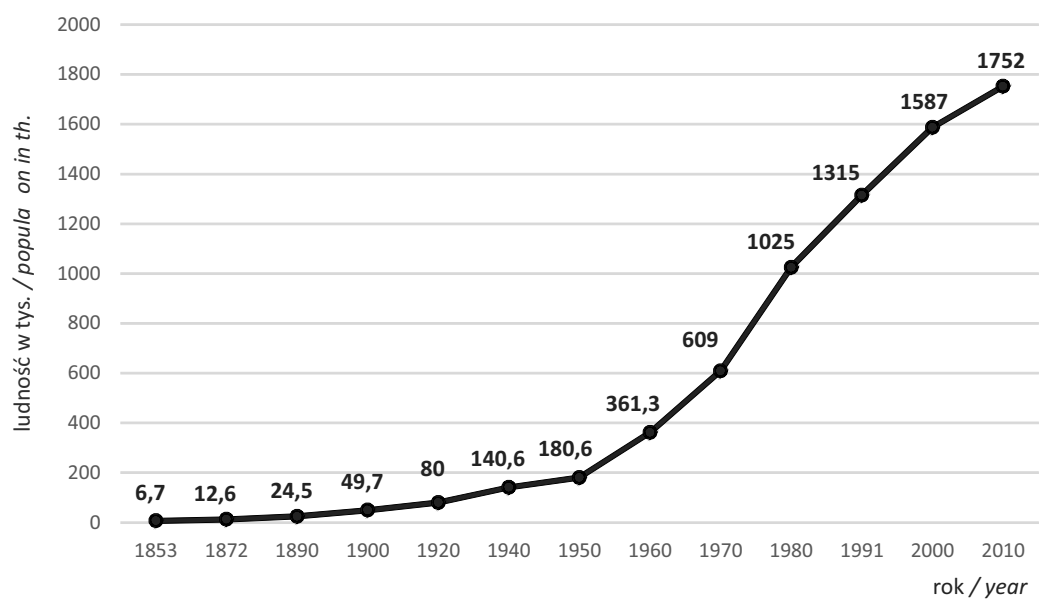

Ryc. 1. Zmiany liczby ludności w Kurytybie w latach 1853-2010

Population changes in Curitiba, 1853-2010

Źródło/Source: Wójtowicz (2014).

oraz rozwój sieci osadniczej Brazylii (Wójtowicz, 2011). Obecnie Kurytyba należy do grupy największych metropolii w Brazylii i liczy ponad 1,7 mln mieszkańców.

Historia osiedlania polskich osadników w Kurytybie sięga 1869 r., kiedy ks. Antoni Zieliński i Edmund Woś-Saporski - uznawani za prekursorów polskiej imigracji w Brazylii - złożyli na ręce cesarza Brazylii Piotra I prośbę o pozwolenie na rozpoczęcie polskiej kolonizacji w stanie Parana (Ciuruś, 1977). Potwierdzeniem wczesnej obecności i pionierskiej działalności Edmunda Woś-Saporskiego w Kurytybie są jego własne słowa: „śród [pisownia oryginalna] obcokrajowców przeważali Francuzi, Anglicy i Niemcy. Polaka nie było w Kurytybie ani jednego" (Woś-Saporski 1974, s. 108). W 1871 r. rada miejska Kurytyby przekazała polskim osadnikom okolice Pilarzinho, leżące w bezpośrednim sąsiedztwie Kurytyby (Ciuruś, 1977). Na skutek tej decyzji jeszcze w tym samym roku grupa polskich emigrantów pochodzących z opolskiego przeniosła się z okolic Blumenau i Brusque w stanie Santa Catarina do Pilarzinho, gdzie przydzielono im działki ziemi do zasiedlenia. Wspomniany Edmund Woś-Saporski odegrał istotną rolę w procesie osiedlania polskich osadników w Kurytybie. Poza skuteczną kampanią formalną na rzecz uzyskania pozwolenia na osadnictwo, angażował się w działania praktyczne w postaci kwaterowania osadników, opłacania ich transportu oraz poszukiwania terenów pod dzierżawę (Głuchowski, 1927).

Do końca lat 80. XIX w. napływ migracyjny Polaków do Brazylii nie był jeszcze znaczący. Według K. Głuchowskiego (1927) do 1889 r. przybyło tam 8080 polskich emigrantów. Natomiast kolejne 25-lecie, było czasem wzmożonej emigracji Polaków do obu Ameryk. Do 1914 r. wielkość fali migracyjnej do Brazylii szacuje się na 100 tys. osób (Groniowski, 1972). Żywiołowość i masowość napływu polskich imigrantów pod koniec XIX w. wynikały z dwóch wzmacniających efekt końcowy powodów: zbyt powolnych przekształceń gospodarczych na terenach polskich pod zaborami oraz liberalnej polityki wjazdowej do państw amerykańskich. To sprawiło, że emigracja za ocean przyjęła formę zjawiska masowego (Pilch, 1984). Pośród głównych przyczyn wyboru Brazylii, jako kierunku migracyjnego, wymienia się przede wszystkim politykę pro-imigracyjną, prowadzoną przez 
władze brazylijskie, które starały się zapełnić deficyt na rynku pracy (Żak, 2017). Z drugiej strony, dramatyczna sytuacja Polaków na ziemiach polskich pod zaborami, wynikająca m.in. z przeludnienia wsi i braku miejsc pracy dla bezrolnych chłopów, których nie był w stanie wygenerować wolno rozwijający się przemysł (Kołodziej, 1982), była kolejnym czynnikiem potęgującym rozmiary ówczesnej emigracji. T. Pindel (2018) różnicuje - w zależności od zaboru - przyczyny, dla których Polacy decydowali się na opuszczenie swoich ziem rodzinnych i emigrację do Brazylii:

- zabór austriacki: ubóstwo, brak ziemi, klęski nieurodzaju, niedożywienie, brak higieny przy jednoczesnym żywiołowym przyroście naturalnym,

- zabór rosyjski: prymitywne i małoobszarowe rolnictwo, kryzys w rolnictwie, wysokie cła, bardzo słabo rozwinięty przemysł, brak pracy, wysoki przyrost naturalny,

- zabór pruski: szykany wobec polskich chłopów ze strony władz, próby przejmowania ziemi, germanizacja.

Autor konkluduje, że tym, co łączyło chłopów ze wszystkich zaborów, było marzenie o swojej ziemi i własnym gospodarstwie, utożsamianymi z sukcesem, dobrobytem i spokojem. Polscy imigranci osiedlali się głównie w trzech stanach: Parana, Rio Grande do Sul i Santa Catarina. Szczególnym obszarem była Kurytyba, wokół której do wybuchu I wojny światowej powstał dosyć zwarty pierścień utworzony przez polskie kolonie. Z informacji publikowanych przez Konsulat Generalny RP w Kurytybie (na podstawie szacunków ks. Jana Pitonia) wynika, że w pierwszej połowie lat 70. XX w. polska diaspora liczyła ok. 35 tys. osób. Obecnie jej wielkość szacuje się na około 90 tys. osób, choć nie brakuje opinii, że może ona liczyć nawet 300 tys. (www.kurytyba.msz.gov.pl).

Ze względu na szczególne znaczenie Kurytyby, uchodzącej w zgodnej opinii badaczy za symboliczną stolicę polskich imigrantów i ich potomków w Ameryce Południowej, autorzy podjęli się identyfikacji współczesnych grup polskiej diaspory, zamieszkujących i współkształtujących przestrzeń społeczną tego miasta. Zasadniczymi celami niniejszego artykułu są: (1) identyfikacja miejsc i obszarów w przestrzeni społecznej Kurytyby, naznaczonych obecnością oraz aktywnością społeczną diaspory polskiej, mających szczególne znaczenie w kontekście kształtowania i podtrzymywania polskiej tożsamości; (2) nakreślenie retrospektywnego profilu polskiego migranta w zależności od reprezentowanego pokolenia migracyjnego, (3) określenie związków pomiędzy współczesną polską diasporą a krajem pochodzenia w kontekście reprezentowanego pokolenia migracyjnego.

\section{Założenia i metody badawcze}

Analiza publikacji naukowych i instytucjonalnych, danych statystycznych oraz autorska inwentaryzacją przestrzeni Kurytyby udokumentowana zbiorem fotografii stanowiła podstawę realizacji pierwszego celu badań, zaś dwóch pozostałych - interpretacja wyników badań społecznych, przeprowadzonych przez autorów w 2017 r, pośród przedstawicieli pięciu pokoleń polonii brazylijskiej zamieszkującej w Kurytybie. Za podstawową metodę badawczą przyjęto badania społeczne z zastosowaniem kwestionariusza ankiety, składającego się z 14 pytań i tzw. metryczki. Dobór próby miał charakter celowy z założeniem zebrania stu kompletnych i prawidłowo wypełnionych formularzy. Kwestionariusze ankietowe zostały przygotowane w języku portugalskim i rozpowszechnione przez sieć internetową w formie plików tekstowych metodą kuli śnieżnej. W ostatniej fazie badań wykorzystano 
również narzędzie Google formularze do tworzenia ankiet on-line. Do rozpowszechniania informacji na temat prowadzonego kwestionariusza, wykorzystano również media społecznościowe, w tym szczególnie członków grup tematycznych na platformie Facebook ${ }^{1}$, których wiąże zainteresowanie tematyką polonijną w Brazylii i Kurytybie.

Spośród zebranych 109 kwestionariuszy ankietowych ostatecznie do dalszych analiz wybrano sto o najwyższym poziomie kompletności i poprawności ich wypełnienia. Pod względem demograficznym, dobór próby jest zróżnicowany, choć zapewne nie reprezentatywny w odniesieniu do ogółu populacji polskiej diaspory, ze względu na istotne trudności w oszacowaniu jej wielkości. Podyktowany charakterem badania celowy dobór próby, zdejmuje z autorów obowiązek zachowania pełnej reprezentatywności.

\section{Kurytyba jako ważna przestrzeń obecności i aktywności społecznej diaspory polskiej}

Kurytyba, od początku historii migracyjnej Polaków w Brazylii, była miejscem ważnym i symbolicznym, pełniąc z czasem funkcję nieformalnej stolicy Polonii latynoamerykańskiej. Jej znaczenie wynikało z faktu największej liczebnie koncentracji polskich imigrantów i osób polskiego pochodzenia i najwyższej aktywności społecznej w sferze publicznej i instytucjonalnej. Była i nadal pozostaje miejscem najstarszych zgromadzeń polonijnych w Ameryce Łacińskiej oraz wydawania polskich czasopism (Łapaj, 2013).

Istotnym wyrazem obecności mniejszości narodowej w kraju przyjmującym jest jej społeczna aktywność. Z jednej strony jest naturalnie włączającą się potrzebą kształtowania wspólnoty diasporycznej na bazie dziedzictwa i tożsamości narodowej, zazwyczaj po osiągnięciu satysfakcjonującego poziomu życia pod względem ekonomicznym. Z drugiej strony może wynikać z potrzeby stworzenia puli inicjatyw prospołecznych, stanowiących wsparcie i pomoc dla migrantów, bądź ich potomków, uzupełniających działania instytucjonalne w ramach prowadzonych polityk publicznych. Wydaje się, że o ile ten drugi typ aktywności społecznej obserwuje się w większym stopniu w krajach o progresywnym charakterze imigracji (np. współczesne migracje Polaków do Wielkiej Brytanii czy też Irlandii), o tyle działania mające na celu krzewienie polskości i podtrzymanie tradycji dotyczą raczej Polonii w krajach, które były docelowym kierunkiem migracyjnym w przeszłości i w tym kontekście dotyczą m.in. Brazylii.

Fakt ten znajduje odzwierciedlenie w przypadku Kurytyby, gdzie już w 1890 r. zainaugurowały działalność najstarsze organizacje polonijne, czyli Towarzystwo Polskie im. Tadeusza Kościuszki, najstarszy polski zespół folklorystyczny „Wisła” oraz Gazeta Polska (1892 r.). Według danych GUS (Baza organizacji i instytucji ..., 2017), w Brazylii funkcjonuje 151 organizacji prowadzonych przez środowiska polonijne. Ich aktywność dotyczy głównie działalności w sferze administracyjno-organizacyjnej, kulturalnej oraz sakralnej. Natężenie działalności społecznej nawiązuje bezpośrednio do miejsc koncentracji Polonii w Brazylii. Ponad połowa ogólnej liczby organizacji polonijnych w Brazylii funkcjonuje bowiem w pierwszych docelowych obszarach polskich migracji, czyli w południowych stanach kraju: Parana, Rio Grande do Sul i Santa Catarina (odpowiednio 21\%, 23\% i 12\%). Należy zaznaczyć, że w Kurytybie działają wszystkie organizacje stanu Parana. Największy

\footnotetext{
${ }^{1}$ Casa da Cultura Polônia Brasil (https://www.facebook.com/groups/396198597064920/); Descendentes de Poloneses no Sul do Brasil (https://www.facebook.com/groups/427604197275153/); Polacy w Kurytybie/ Poloneses em Curitiba (https://www.facebook.com/groups/356546367802028/)
} 
udział w strukturze organizacji polonijnych w Brazylii mają placówki prowadzące aktywność w sferze artystyczno-kulturalnej (57\%), w sferze sakralnej (32\%) i działalności administracyjno-organizacyjnej (13\%) (ryc. 2).

Znaczenie Kurytyby jako symbolicznego centrum polskiej diaspory wyrażają również przestrzenie publiczne i obiekty kulturowe. Szczególnym miejscem na mapie miasta jest Park im. Jana Pawła II (Bosque Polones Papa Joao Paulo II), teren zieleni miejskiej specjalnie zaaranżowany z okazji pierwszej wizyty w tym kraju papieża Polaka (fot. 1). Ważną i zarazem cenną kulturowo atrakcją tego terenu jest zespół kilkunastu XIX-wiecznych drewnianych domów sprowadzonych z terenu stanu Parana, w których dawniej mieszkali polscy osadnicy (fot. 2). Ważnym obiektem kulturowym, nawiązującym symbolicznie do migracyjnej historii Polaków oraz mocno zakorzenionej w nich religii katolickiej, jest zlokalizowana w parku rzeźba „Jezusa Migranta”, wykonana z okazji wizyty Papieża w Kurytybie, a następnie podarowana jej mieszkańcom (www.magazynpolonia.com). Park jest również miejscem celebracji ważnych świąt religijnych i narodowych związanych z historią Polski oraz demonstracji przywiązania do polskich tradycji. Przestrzeń publiczna Kurytyby jest naznaczona polską tradycją poprzez:

- pomniki i tablice pamiątkowe poświęcone znanym i cenionym na całym świecie rodakom (m.in. św. Janowi Pawłowi II, Mikołajowi Kopernikowi, Lechowi Wałęsie),

- nazwy ulic, których patronami są zasłużone osoby polskiego pochodzenia,

- obecność polskich instytucji państwowych, w tym przede wszystkim Konsulatu Generalnego RP.

Silnie zakorzenione w przestrzeni społecznej miasta jest duchowieństwo polonijne, reprezentowane przez instytucje i organizacje kościelne takie jak: Polska Misja Katolicka,

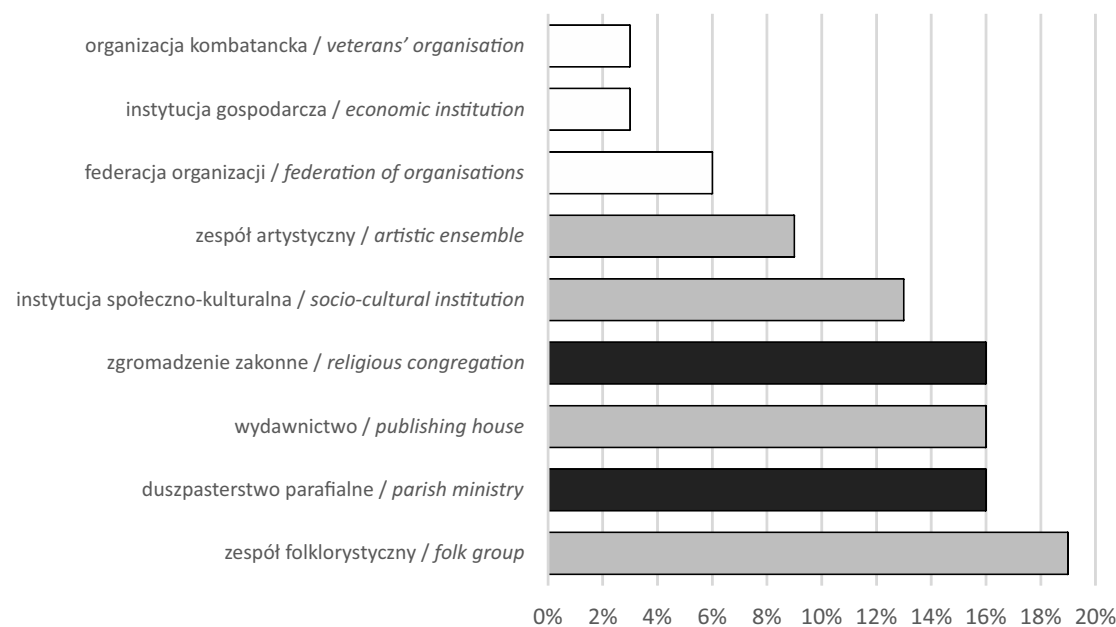

Ryc. 2. Struktura organizacji i instytucji polonijnych w Kurytybie według typu prowadzonej działalności (kolor biały: instytucje o profilu organizacyjno-administracyjnym; szary: organizacje kulturalne; czarny: instytucje sakralne)

Typology and structure of Polonia-related institutions and organisations in Curitiba (in white: institutions of an organisational and administrative profile; in grey: cultural organisations; in black: religious organisations) Źródło: Opracowanie własne na podstawie Bazy organizacji i instytucji polskich .... (2017).

Source: authors' own elaboration based on Bazy organizacji i instytucji polskich .... (2017). 


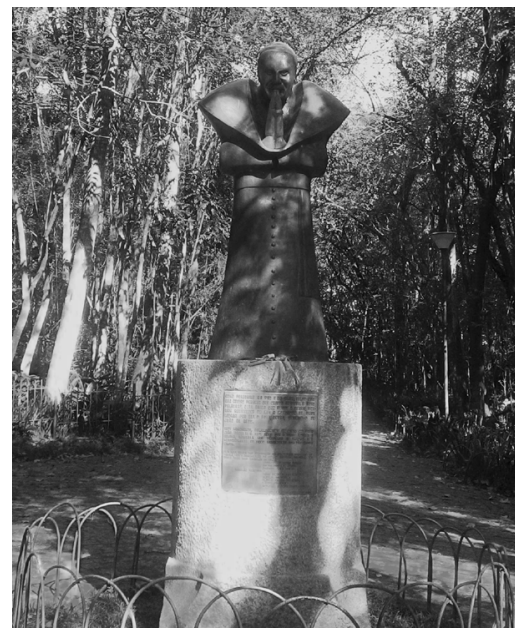

Fot. 1. Pomnik św. Jana Pawła II Monument to John Paul II Źródło: zbiory własne, tak samo fot. 2. Source: authors' own collection, like fot. 2.

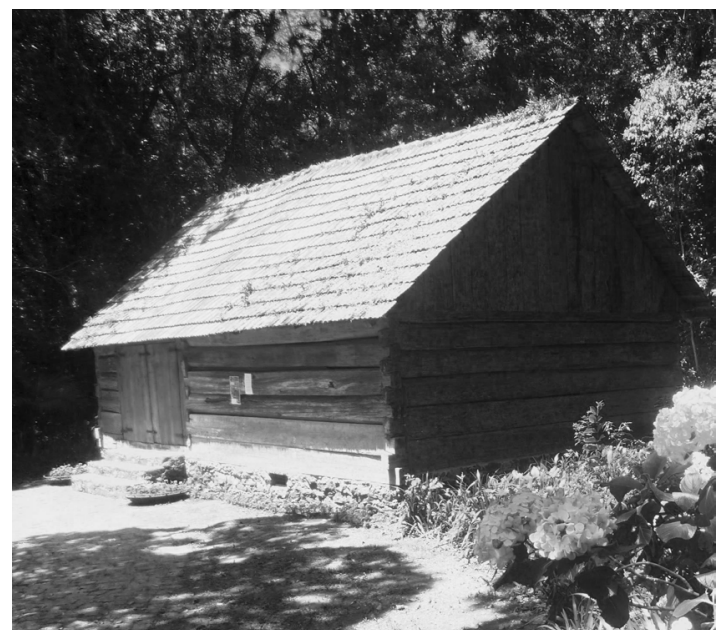

Fot. 2. Dom polskich osadników z XIX w. w parku im. Jana Pawła II w Kurytybie $19^{\text {th }}$ century cabin of Polish settlers located in Pope John Paul II Park in Curitiba

oraz Kościół im. Św. Stanisława (www.msz.gov.pl/pl/p/kurytyba_br_k_pl). Istotnym faktem, było również uruchomienie w 2009 r. jedynej w Ameryce Południowej Katedry Języka Polskiego w Uniwersytecie Federalnym Parany w Kurytybie (Universidade Federal do Paraná). Większość studentów ma świadomość swojego polskiego pochodzenia i wyraża chęć poszukiwania korzeni oraz odnajdowania tożsamości narodowej przodków poprzez studiowanie polonistyki. Część studentów traktuje znajomość języka polskiego nie tylko w wymiarze symbolicznym, ale także pragmatycznym uznając, że może być przydatny zawodowo w pracy tłumacza, nauczyciela bądź przewodnika (Pluta, 2014).

\section{Charakterystyka społeczno-demograficzna członków polskiej diaspory w Kurytybie w świetle badań społecznych}

Pomimo dystrybucji formularzy ankietowych drogą elektroniczną, pozyskano porównywalną liczbę ankiet od osób z różnych przedziałów wiekowych: 50 lat i więcej stanowiły 34\%, 30 do 49 lat - 25\%, zaś poniżej 30 lat - 30\%. Co dziesiąta osoba nie udzieliła odpowiedzi na pytanie o wiek. W strukturze płci badanych nieznacznie dominowała płeć żeńska (54\%). Pod względem deklarowanego stanu cywilnego największą grupę stanowiły osoby pozostające w związkach małżeńskich oraz osoby stanu wolnego (odpowiednio 47\% i 37\%). Natomiast osoby rozwiedzione i owdowiałe stanowiły $8 \%$ i $7 \%$.

Pod względem poziomu wykształcenia wyraźnie dominują osoby legitymujące się wykształceniem wyższym (76\%) oraz średnim (12\%), co potwierdza, że polscy imigranci bądź ich potomkowie cechują się wysokim poziomem kapitału ludzkiego. Kolejnymi są odpowiednio wykształcenie zawodowe (6\%) oraz wykształcenie podstawowe (5\%), które deklarują osoby w podeszłym wieku, co zgodne jest ze spostrzeżeniem badaczy polskich 
migracji do Brazylii, o pierwszych pokoleniach przybyłych Polaków, w których dominowały osoby słabo wykształcone, wywodzące się z obszarów wiejskich. Również trudności w dostępie do publicznej oświaty w pierwszej połowie XX w. mogą być przyczyną tak kształtującej się struktury wykształcenia.

W strukturze zawodowej dominują urzędnicy, nauczyciele, przedsiębiorcy i specjaliści (ryc. 3). Natomiast pośród innych deklarowanych profesji (maksymalnie 2 wskazania) wymieniane były następujące zawody: naukowiec, dziennikarz, lekarz, tłumacz, prawnik, muzyk. Należy zaznaczyć, że w grupie respondentów zaznacza się pewna nadreprezentacja osób o relatywnie wysokim poziomie wykształcenia i wykonujących zawody o wysokim prestiżu społecznym, na co rzutowała w dużej mierze metoda doboru respondentów. Niezależnie od tego, z całą pewnością można stwierdzić, że systematycznie poprawia się status społeczno-zawodowy potomków polskich osadników. Wynika to z faktu, że szczególnie w okresie powojennym, pośród polskich imigrantów dominowali już robotnicy wykwalifikowani i inteligencja (por. Mazurek, 2009), ale również z aspiracji i potrzeb ustawicznego rozwoju przedstawicieli polskiej diaspory bez względu na pokolenie, które reprezentują. E. Budakowska (2007) potwierdza fakt awansu społecznego polskich potomków, podkreślając zarazem, że umożliwiał im „pokonywanie etnicznych granic stygmatyzacji”.

W ramach przeprowadzonych badań udało się dotrzeć do bardzo zróżnicowanej grupy przedstawicieli polskiej diaspory, począwszy od mieszkańców Kurytyby posiadających przodków w co najmniej czwartym pokoleniu, na współczesnych polskich imigrantach kończąc. W największym stopniu była reprezentowana grupa osób, posiadająca polskie korzenie w trzecim pokoleniu (45\%), co czwarta osoba ma polskich przodków w drugim pokoleniu, a co siódma - w czwartym. Najmniej liczebne były grupa osób reprezentujących pierwsze pokolenie oraz współczesnych imigrantów (odpowiednio 12\% i 5\%), co odzwierciedla fakt wyciszanego strumienia migracji do Brazylii.

Pod względem przynależności państwowej, aż 70\% badanych posiada obywatelstwo brazylijskie, kolejne $12 \%$ - podwójne obywatelstwo polsko-brazylijskie, natomiast zaled-

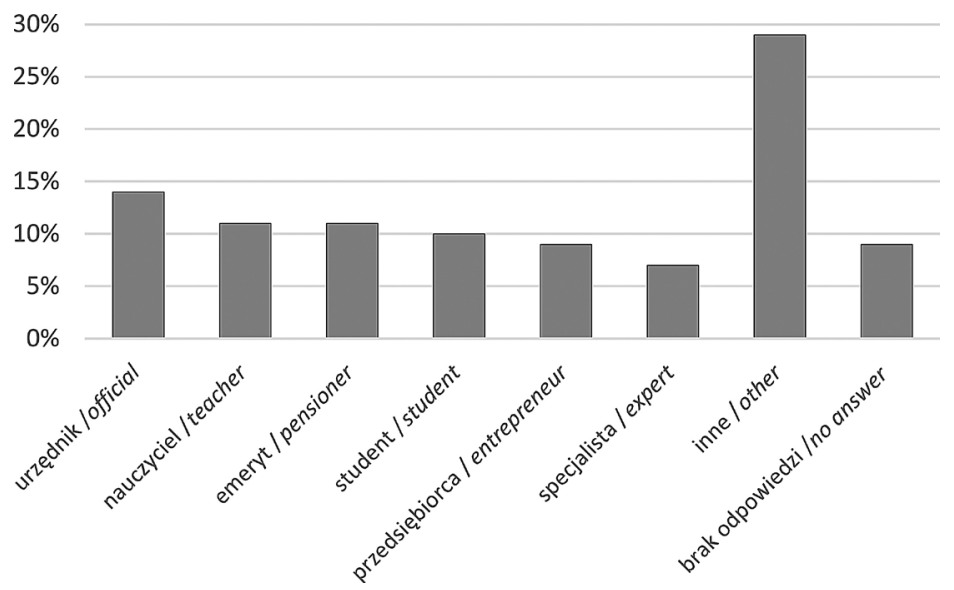

Ryc. 3. Status zawodowy respondentów

Occupational status of respondents

Opracowanie własne, tak samo pozostałe ryciny/Authors’ own elaboration, like remaining figures. 
wie 5\% badanych deklaruje posiadanie polskiego obywatelstwa. Istnieje istotna zależność pomiędzy posiadanym obywatelstwem a pokoleniem, jakie reprezentują potomkowie polskich migrantów (ryc. 4). Największy odsetek osób posiadających obywatelstwo brazylijskie deklarują potomkowie Polaków w czwartym i trzecim pokoleniu (po 93\%), natomiast najniższy - w pierwszym pokoleniu oraz współcześni imigranci (odpowiednio 58\% i 20\%). Co oczywiste, polskie obywatelstwo deklarują głównie imigranci z Polski (80\%), natomiast podwójne polsko-brazylijskie obywatelstwo posiadają potomkowie polskich migrantów w drugim i pierwszym pokoleniu (odpowiednio 68\% i 58\%).

Istotnych trudności przysporzyło ankietowanym określenie czasu przybycia ich polskich przodków do Brazylii. Niemal co czwarta osoba nie udzieliła odpowiedzi, co można tłumaczyć brakiem przekazu informacji w rodzinie czy też zagubieniem dokumentacji polskich przodków. Z deklarowanego czasu przybycia do Brazylii wynika, że Polonię w Kurytybie tworzą w istotnej mierze potomkowie starych fal migracyjnych, gdyż co trzeci badany wskazał XIX w. jako okres przybycia jego przodków do Brazylii, a kolejne 32\% - przed II wojną światową (ryc. 5). I chociaż, jak opisywał K. Głuchowski (1927) we wskazanych okresach polscy imigranci osiedlali się głównie na obszarach wiejskich, to okres wzmożonego uprzemysłowienia trwający od połowy XX w. mógł być przyczyną migracji ich potomków miast, w tym przede wszystkim - do Kurytyby.

Poza czasem przybycia do Brazylii, równie znamienny i potwierdzający prawidłowości wykazywane przez badaczy (m.in. Ciuruś, 1977; Kula, 2012; Łapaj, 2013; Malczewski, 2008; Mazurek, 2009; Żak, 2017), jest wybór miejsca (ryc. 6). Pierwsze fale polskich imigrantów osiedlały się głównie w obszarach wiejskich i wynika to jednoznacznie z deklaracji o miejscu zamieszkania potomków polskich w czwartym pokoleniu. Natomiast im krótsza historia pobytu w Brazylii polskiej diaspory, tym wyraźniej wzrasta wybór miast na miejsca zamieszkania oraz wewnętrzne migracje potomków polskich osadników ze wsi do miast.

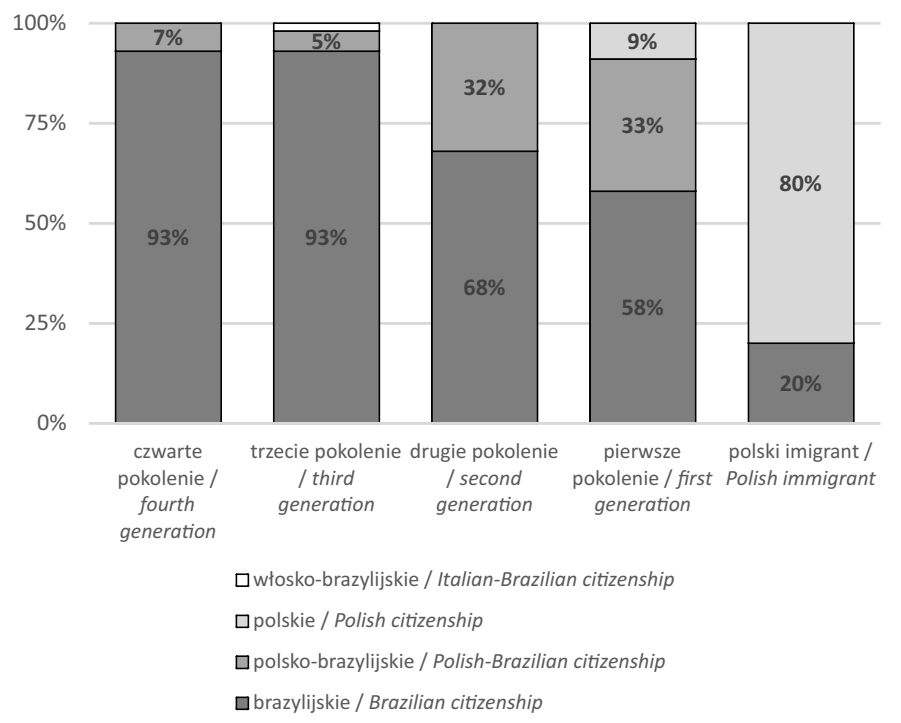

Ryc. 4. Obywatelstwo deklarowane przez respondentów według pokolenia migracyjnego Nationality declared by respondents, by migration generation 


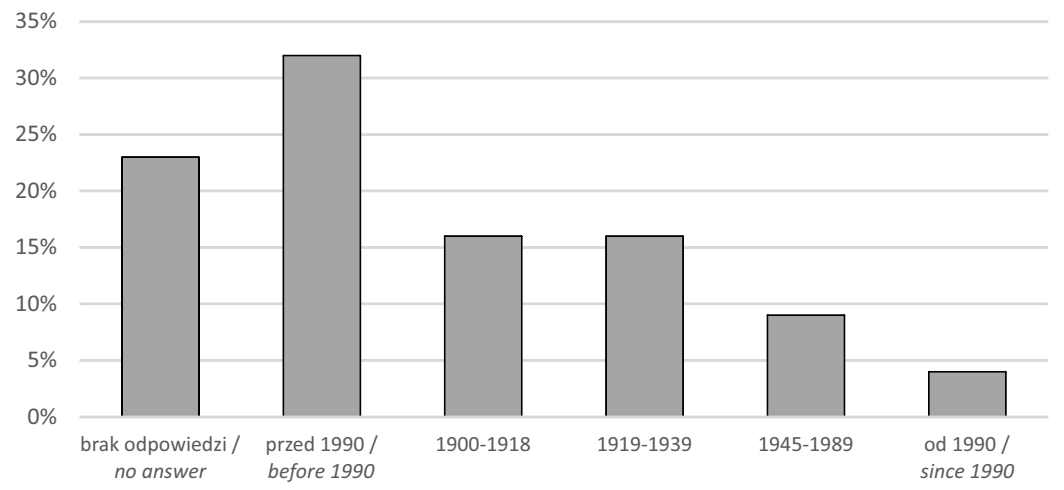

Ryc. 5. Deklarowany czas przybycia do Brazylii respondentów bądź ich przodków Declared time of arrival in Brazil among respondents or their ancestors

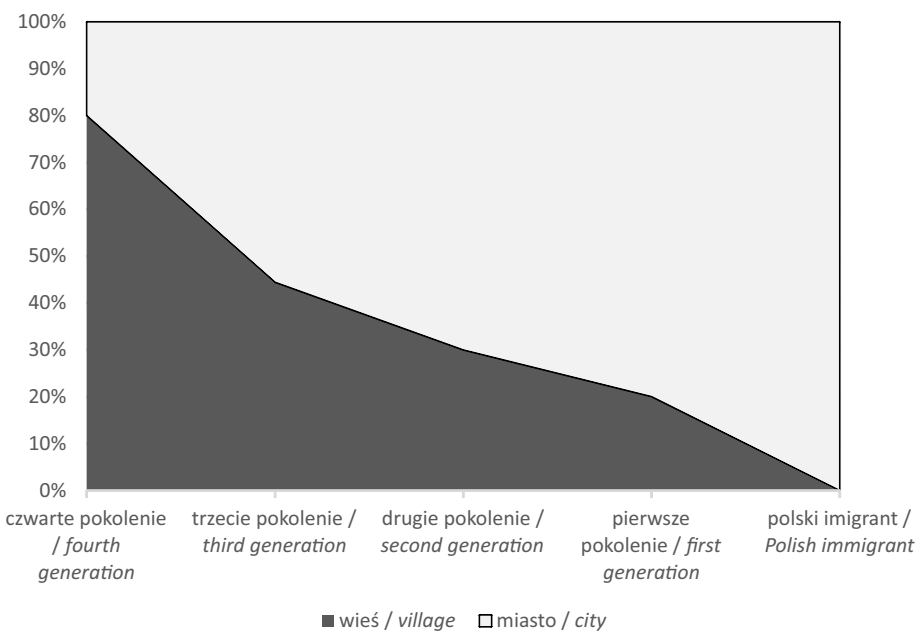

Ryc. 6. Obszary wyboru miejsca zamieszkania przez polskich migrantów w Brazylii według czasu przybycia do kraju przyjmującego

Residential areas chosen by Polish migrants to Brazil, by time of arrival

W kwestionariuszu zawarto również pytanie o czas zamieszkania w Kurytybie. O znacznym poziomie zakorzenienia w mieście świadczy fakt, że niemal $60 \%$ ankietowanych mieszka w nim od urodzenia, 6\% zamieszkało przed 1990 r, a jedynie co piąty został mieszkańcem po 1990 r. W badaniu wzięło również udział 11\% osób, które nie mieszkają w Kurytybie, ale w jej strefie podmiejskiej, natomiast w mieście tym studiują bądź pracują.

Polska diaspora w Brazylii jest dość znacząco rozproszona w przestrzeni miasta, co oznacza, że jest to społeczność mocno wymieszana i wtopiona w lokalne struktury społeczne, wykazująca zarazem jeden z najwyższych poziomów asymilacji, czyli asymilację strukturalną (Gordon, 1964; za Budyta-Budzyńska, 2011). Bezsprzecznie wpływ na to ma kilkupokoleniowy charakter polskich migracji do Brazylii. Badacze wskazują, że jako pierwsze 
były zasiedlane podmiejskie dzielnice Abranches i Pilarzinho (Woś-Saporski, 1974), które obecnie znajdują się w obrębie granic administracyjnych miasta, w jego północnej części. W latach 70. XX w. polscy imigranci i ich potomkowie osiedlali się głównie w dzielnicach: Abranches, Pilarzinho, Santa Candida, Barreirinha, Cachoeira, Mercês, Portão, Novo Mundo, Vila Feliz, Seminário, Orleans, Atuba, Bacacheri i Vila Tinguí.

Wyniki badań potwierdzają tezę o istotnym rozproszeniu Polonii w Kurytybie (ryc. 7). W przestrzeni miasta zaznacza się kilka obszarów wyższej koncentracji obywateli polskiego

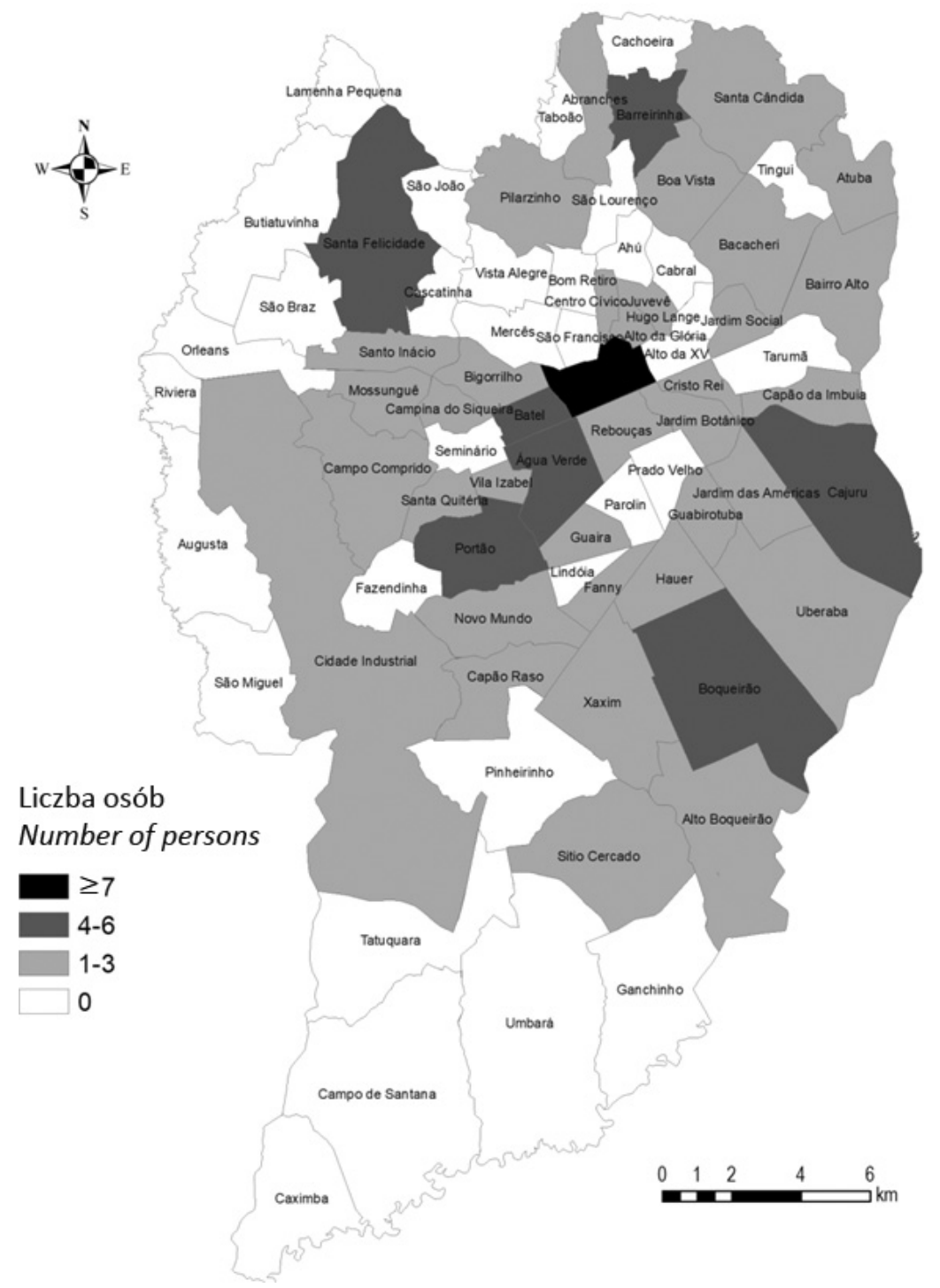

Ryc. 7. Deklarowane miejsce zamieszkania respondentów w przestrzeni miejskiej Kurytyby Respondents' declared places of residence in the urban area of Curitiba 
pochodzenia. Jest to przede wszystkim ścisłe centrum miasta (Centro) oraz takie dzielnice, jak: Abranches, Água Verde, Batel, Boqueirão, Cajuru, Portão i Santa Felicidade. Według danych Instytutu Badań i Planowania Urbanistycznego Kurytyby dzielnica Abranches jest największym miejscem koncentracji rodzin polskiego pochodzenia. Warto podkreślić, że większość z wymienionych wyżej dzielnic cechuje zbliżony do całego miasta poziom rozwoju społeczno-ekonomicznego oraz dominacja klasy średniej w strukturze społecznej. Dzielnice Centro, Batel i Água Verde uchodzą za szczególnie prestiżowe pod względem rezydencjonalnym. Za dobre dzielnice, notujące wyższe niż przeciętne wskaźniki jakości życia w mieście, uchodzą również dzielnice Santa Felicidade i Portão. Większe skupiska Polonii notuje się również w dzielnicy Barreirinha, stanowiącej ważny obszar dla pierwszych polskich osadników, nazywany zwyczajowo polską kolonią.

\section{Uwarunkowania poczucia polskości i związków z krajem pochodzenia przodków}

Jak podkreśla E. Ciuruś (1977) wielu Brazylijczyków polskiego pochodzenia aktywnie uczestniczy we wszystkich dziedzinach życia Brazylii. Wykształciła się tam miejscowa młoda inteligencja, która pomimo, że z dystansu czasu spogląda na drogę przebytą przez ich pradziadów i ojców, wyraża zainteresowanie i potrzebę udokumentowania swojej przeszłości oraz poznania wkładu swoich przodków w rozwój ich ojczyzny, czyli Brazylii.

W celu określenia stopnia poczucia polskości, zapytano respondentów m.in. o poziom znajomości języka polskiego, utrzymywanie kontaktów z rodziną w Polsce, wyjazdy do Polski czy kultywowanie polskich tradycji. Znajomość języka polskiego pośród badanych należy określić jako słabą, bowiem 41\% ankietowanych nie zna wcale języka przodków, a kolejne 31\% określa tę znajomość jako podstawową. Załamanie znajomości języka pośród polskich imigrantów i ich potomków można tłumaczyć m.in. procesem żywiołowej nacjonalizacji Brazylii, prowadzonej przez prezydenta G. Vargasa w latach 30. XX w., w ramach której zakazano m.in. nauczania i posługiwania się językiem obcym. Fakt zaniku posługiwania się językiem polskim w Brazylii potwierdzają również zapisy w raporcie Ministerstwa Spraw Zagranicznych z 2009 r. (Raport o sytuacji Polonii..., 2009). Biegłą umiejętność posługiwania się polszczyzną zadeklarowało 16\% badanych. Z pogłębionych badań nad bilingwizmem polsko-portugalskim polskiej diaspory, zrealizowanych w Kurytybie w latach 90. XX w. (Miodunka, 2003) wynika jednak, że osoby polskiego pochodzenia nie posługują się klasyczną polszczyzną. Jest to raczej swoisty kod mówiony języka polskiego w takiej odmianie stylistycznej, której nauczyli się w domu, czyli potocznej, z domieszką elementów regionalnych i gwarowych. Znajomość kodu pisanego ogranicza się jedynie do świadomości, że polski i portugalski używają tych samych liter łacińskich (Miodunka, 2018).

Trudno wykazać jednoznaczny związek pomiędzy czasem zasiedzenia w Brazylii a poziomem znajomości języka polskiego (ryc. 8). W największym stopniu posługują się biegle polszczyzną osoby będące potomkami Polaków w pierwszym pokoleniu (33\%) i co ciekawe - w trzecim i czwartym pokoleniu (odpowiednio 11\% i 7\%). Ten fakt w sposób oczywisty wskazuje na związek pierwszego pokolenia potomków polskich z krajem przodków oraz potwierdza spostrzeżenia innych badaczy, że następuje pewien renesans zainteresowania Polską ze strony przedstawicieli najmłodszych pokoleń polskiej diaspory. W tym kontekście interesujący jest fakt, że nieznajomość języka polskiego jest ponownie 


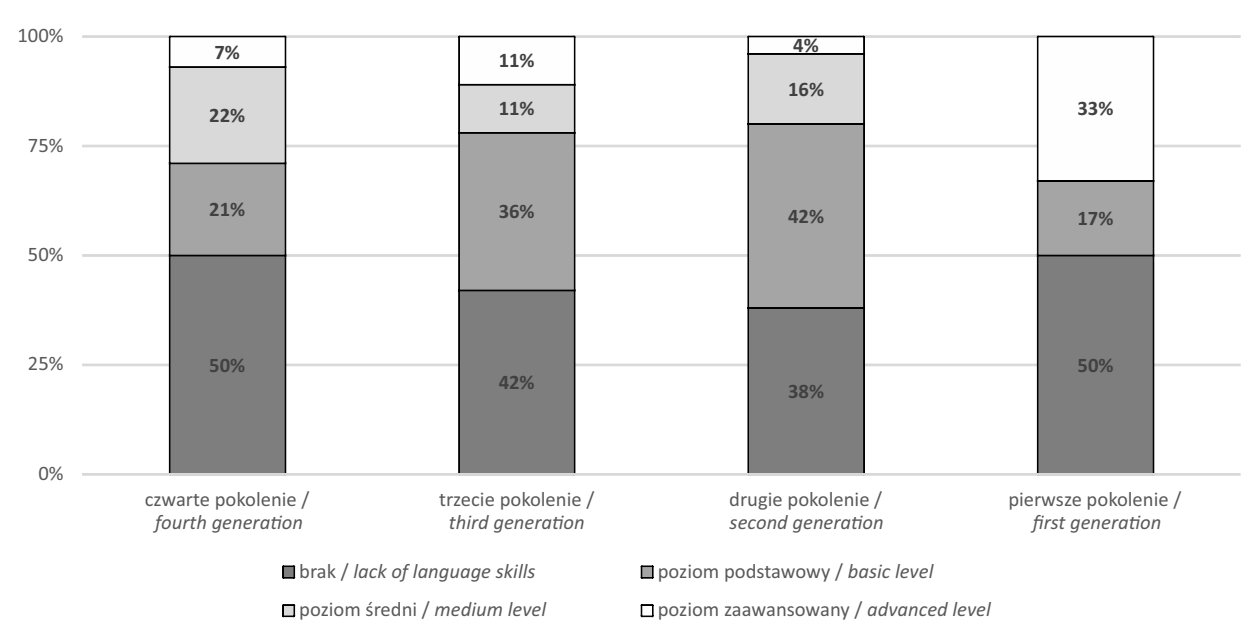

Ryc. 8. Poziom znajomości języka polskiego wśród respondentów według pokolenia migracyjnego Respondents' Polish language skills by migration generation

najczęściej wskazywana przez potomków Polaków w pierwszym oraz czwartym pokoleniu (po 50\% ogółu wskazań).

Niemal 80\% respondentów nie utrzymuje kontaktów z rodziną w Polsce w żadnej formie. Wiąże się to przede wszystkich z nieznajomością adresów korespondencyjnych czy też brakiem znajomości języka polskiego, która uniemożliwia podtrzymywanie stałych relacji i więzi z polską rodziną. W największym stopniu kontakty z rodziną w Polsce posiadają obecni imigranci i ich przodkowie w pierwszym pokoleniu (odpowiednio ponad 75\% i około 40\%). Z kolei osoby deklarujące się jako potomkowie polskich rodzin w czwartym pokoleniu nie posiadają żadnych związków rodzinnych. W przypadku przedstawicieli trzeciego i drugiego pokolenia kontakty z rodziną w Polsce ma poniżej 25\% badanych.

Biorąc pod uwagę, że większość respondentów nie utrzymuje kontaktu z rodziną w Polsce, nie dziwi fakt, że ponad 50\% ankietowanych nigdy nie było w Polsce. Interesujące wydaje się być spostrzeżenie, że nie ma większej zależności pomiędzy czasem migracji do Brazylii a wizytami w Polsce (ryc. 9). W przypadku kilkukrotnych pobytów w kraju ojczystym przodków poziom wskazań oscyluje wokół 20-25\%, z wyjątkiem polskich potomków w czwartym pokoleniu, pośród których 7\% było w Polsce więcej niż jeden raz. Jednorazowy pobyt deklarowali najczęściej przedstawiciele polskiej diaspory w pierwszym pokoleniu (42\%) i czwartym pokoleniu (29\%). Natomiast największą grupę osób, które nigdy w Polsce nie były, stanowią potomkowie w drugim i czwartym pokoleniu (odpowiednio $67 \%$ i $64 \%)$.

Pomimo stosunkowo słabych kontaktów z Polską i żyjącą tam rodziną, zdecydowana większość respondentów (70-80\% w zależności od pokolenia) deklaruje podtrzymywanie i przekazywanie z pokolenia na pokolenie polskich tradycji, głównie religijnych i ludowych, ale także kulinarnych, bez względu na reprezentowane pokolenie migracyjne Znaczenie kościoła katolickiego oraz wysoki stopień religijności przedstawicieli Polonii, a także rola kultury ludowej wiązanej głównie z polskim folklorem, są nieodzownymi elementami podtrzymywania tożsamości narodowej. Z pewnością sposób celebrowania najważniejszych 


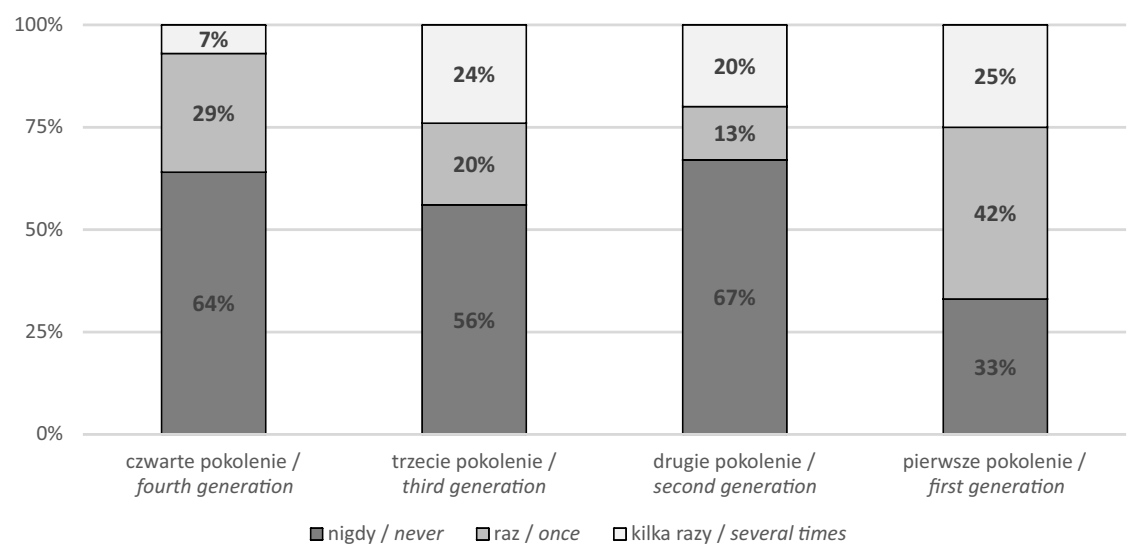

Ryc. 9. Częstotliwość wyjazdów do Polski według czasu przybycia do kraju przyjmującego Frequency of visits to Poland by time of arrival in host country

świąt chrześcijańskich ma - poza kluczowym wymiarem duchowym - również wymiar atrakcyjnej formuły spędzania czasu z najbliższą rodziną, z zachowaniem typowych polskich obyczajów religijnych i ludowych oraz symboliką stołu zastawionego tradycyjnymi polskimi potrawami.

Największą grupę polskiej diaspory tworzą osoby, które stanowią trzecie pokolenie polskich imigrantów. Znaczna część ankietowanych, nie jest w stanie określić, kiedy ich przodkowie dotarli do Brazylii, jednak wyniki badań potwierdzają wyraźną przewagę migracji sprzed I wojny światowej. Interesująca jest pewna biegunowość pomiędzy wyraźnym procesem zaniku znajomości języka polskiego i słabych kontaktów z rodziną w Polsce a wyrażaną przez trzecie i czwarte pokolenie polskich imigrantów potrzebą podtrzymywania polskich tradycji i zachowania polskiego dziedzictwa historyczno-kulturowego. Są to częstokroć osoby bardzo dobrze wykształcone i zamożne, reprezentujące średnie i wyższe warstwy społeczne w Kurytybie.

\section{Podsumowanie}

Jak wynika z przeprowadzonych badań, pomimo zanikającej wśród potomków polskich osadników znajomości języka polskiego, sporadycznych kontaktów z rodziną w Polsce oraz stosunkowo rzadko deklarowanych wizyt w kraju przodków, polskość jest wyraźne podkreślana przez polską diasporę w Kurtybie. Jest ona demonstrowana w przestrzeni publicznej, naznaczonej obecnością elementów polskiego dziedzictwa historyczno-kulturowego (ze szczególnym udziałem i symboliczną rolą kościoła katolickiego) oraz wydarzeniach kulturalnych i edukacyjnych. Również w zachowaniach społecznych polonii brazylijskiej, kultywującej polskie tradycje i obyczaje oraz wykazującej znaczącą aktywność społeczną w sferze publicznej. W tym kontekście szczególnie istotny wydaje się renesans poczucia polskości i poszukiwania źródeł polskiej tożsamości pośród stosunkowo młodych - dobrze wykształconych oraz reprezentujących średnie i wyższe klasy społeczne - osób, stanowiących trzecie i czwarte pokolenie polskich imigrantów. 
Z całą pewnością można stwierdzić, że czas, który upłynął od początku osiedlania się pierwszych polskich osadników w Brazylii i Kurytybie, liczony od co najmniej piątego pokolenia, jest okresem systematycznego pogłębiania się procesów integracji i asymilacji społecznej. Tym bardziej istotne jest niesłabnące poczucie związków polonii brazylijskiej z krajem ojczystym przodków, które wychodzi zdecydowanie poza sferę deklarowanego poczucia polskości i dotyczy zachowań i aktywności, wynikających z chęci kultywowania i krzewienia polskich idei zarówno w życiu prywatnym, jak i publicznym.

\section{Piśmiennictwo}

Budakowska E., 2007, W poszukiwaniu etniczności. Ruch Braspol w Brazylii - współczesna interpretacja, Wydawnictwo Uniwersytetu Warszawskiego, Warszawa.

Budyta-Budzyńska M., 2011, Adaptacja, integracja, asymilacja - próba ujęcia teoretycznego, [w:] M. Budyta-Budzyńska (red.), Integracja czy asymilacja? Polscy imigranci na Islandii, Wydawnictwo Naukowe Scholar, Warszawa, s. 44-65.

Ciuruś E., 1977, Polacy w Brazylii, Polonijne Centrum Kulturalno-Oświatowe UMCS, Lublin.

Garcez L., 2006, Curitiba - Evolucao Urbana, Rio de Janeiro, Curitiba.

Głuchowski K., 1927, Wśród pionierów polskich na antypodach. Materiały do problemu osadnictwa polskiego w Brazylii, Wydawnictwo Instytutu Naukowego do Badań Emigracji i Kolonizacji, Warszawa.

Gordon M., 1964, Assimilation in American Life: The Role of Race, Religion and National Origins, Oxford University Press, New York.

Groniowski K., 1972, Polska emigracja zarobkowa w Brazylii 1871-1914, Zakład Narodowy Imienia Ossolińskich, Wydawnictwo Polskiej Akademii Nauki, Warszawa.

GUS, 2017, Baza organizacji i instytucji polskich i polonijnych za granica, 2017, Główny Urząd Statystyczny, Warszawa.

Kołodziej E., 1982, Wychodźstwo zarobkowe z Polski 1918-1939, Książka i Wiedza, Warszawa.

Kula M., 2012, Polono-Brazylijczycy i parę kwestii im bliskich. Instytut Studiów Iberyjskich i Iberoamerykańskich Uniwersytetu Warszawskiego, Warszawa.

Łapaj J., 2013, Polacy w Brazylii - aspekty historyczne i współczesność. Pisma Humanistyczne, 10, s. 11-29, http://bazhum.muzhp.pl (dostęp: 10.11.2017).

Malczewski Z., 2008, Ślady polskie w Brazylii, Instytut Studiów Iberyjskich i Iberoamerykańskich Uniwersytetu Warszawskiego, Warszawa.

Mazurek J., 2009. Obecność polska w Brazylii, [w:] J. Mazurek (red.), Polacy pod Krzyżem Południa, Instytut Studiów Iberyjskich i Iberoamerykańskich Uniwersytetu Warszawskiego, Warszawa, s. 11-64.

Miodunka W.T., 2003, Bilingwizm polsko-portugalski w Brazylii. W stronę lingwistyki humanistycznej, Studia Latynoamerykańskie, 6, Uniwersytet Jagielloński, Kraków.

Miodunka W.T., 2018, Bilingwizm polsko-portugalski w Brazylii. Od znajomości polszczyzny do tłumaczenia literatury polskiej na portugalski, Postscriptum Polonistyczne, 1, 21, s. 201-220.

Pilch A. (red.), 1984, Emigracja z ziem polskich w czasach nowożytnych i najnowszych (XVIII-XX w.), Państwowe Wydawnictwo Naukowe, Warszawa.

Pindel T., 2018, Za horyzont. Polaków latynoamerykańskie przygody, Wydawnictwo Znak, Kraków. 
Pluta A., 2014, [Brazylia przed Mundialem] Kto czyta Różewicza w oryginale?, Kultura Liberalna, 281, https://kulturaliberalna.pl/2014/05/29/brazylia-mundialem-czyta-rozewicza-oryginale/ (dostęp: 04.02.2019).

Rabinovitch J., 1992, Curitiba: towards sustainable urban development, Environment and Urbanization, 4, s. 62-73.

Raport o sytuacji Polonii i Polaków za granica, 2009, Ministerstwo Spraw Zagranicznych, Warszawa. Woś-Saporski E.S., 1974, Pamiętnik z brazylijskiej puszczy, Wydawnictwo Śląskie, Katowice.

Wójtowicz M., 2011, Proces urbanizacji a przekształcenia brazylijskich obszarów metropolitalnych na przełomie XX i XXI wieku, [w:] M. Soja i A. Zborowski (red.), Człowiek w przestrzeni zurbanizowanej, Instytut Geografii i Gospodarki Przestrzennej Uniwersytetu Jagielońskiego, Kraków, s. $175-189$.

Wójtowicz M., 2014, Racial and economic segregation in Curitiba, [w:] M. Wójtowicz, A. Winiarczyk-Raźniak (red.), Environmental and socio-economic transformations in developing areas as the effect of globalization, Wydawnictwo Naukowe Uniwersyetetu Pedagogicznego, Kraków, s. $34-48$.

Żak M., 2017, Propaganda polskiego wychodźstwa do Brazylii w świetle miesięcznika "Morze" (1924-1939), Zeszyty Naukowe Państwowej Wyższej Szkoły Zawodowej im. Witelona w Legnicy, 22, 1, s. 69-92.

\section{Summary}

This article addresses the issue of the modern Polish diaspora in Curitiba - an important and symbolic city in the context of the Polish migration to Brazil ongoing since the second half of the $19^{\text {th }}$ century. An overview of Polish migratory flows to Curitiba through time is offered, with account taken of the city's significance as unique space for social activeness on the part of Brazilian-resident Poles. The work detailed here has had as its main aims the identification of "Polish" places and areas in Curitiba's social space, the profiling of the Polish migrant, and the assessment of relations between the modern Polish diaspora and the mother country, in the contexts of different migration generations.

The city of Curitiba has been perceived as a significant and symbolic place for Polish migrants since the very beginning of Polish migration history. With time, it has become the informal "capital city" of Latin American Polonia, being home to the largest numbers of Polish migrants and people with Polish roots. Curitiba has also been the city in which Poles have consistently been most active, both socially and institutionally. This social activeness is a vital expression of the presence of a particular minority in a host country. It is also a reflection of the need for pro-social initiatives to be pursued with a view to migrants gaining support. Thus the social activities taken up by members of the Polish diaspora in Brazil arise out of a need for national identity to be sustained and Polish traditions promoted. The number of Polish organisations is a visible expression of social activeness, there being no fewer than 151 such organisations in Brazil, 21\% of them operating in Curitiba. Most are oriented towards artistic, cultural, religious and administrative-organisational activity.

The significance of Curitiba as a symbolic centre for the Polish diaspora is also expressed in public spaces and cultural objects. Curitiba's public space is marked by the presence of Polish monuments, plaques and street names commemorating famous and apprecia- 
ted Poles, as well as by Polish national institutions. There is only one Department of Polish Language in Latin America, and it is at the Federal University of Parana in Curitiba.

For the purposes of this article, a survey among a significantly differentiated group of respondents has been carried out. The group comprised representatives of the Polish diaspora having Polish ancestors three generations back, as well as modern Polish migrants. The Polish diaspora in Curitiba is found to be dispersed spatially, and deeply immersed in local social structures. Yet, there are several areas with higher concentrations of people having Polish roots. The level of social and economic development there does not differ significantly from that in the rest of the city, with the middle class prevailing in the social structure.

The survey shows that, while the descendants of Polish settlers are not fluent Polish speakers and do not visit the "mother country" very often, Polishness is demonstrated by the diaspora present in Curitiba. It is clearly visible in public space of the city as there are numerous objects representing Polish historical and cultural heritage, as well as cultural events. It is also visible in social behaviour of Brazilian Polonia, who still cultivate Polish traditions and customs. Their social activeness is also demonstrated in the public sphere. Since the day Poles first settled in Brazil, and in Curitiba, these people have been integrating steadily with Brazilians and assimilating into their society. This makes the strong bond with the "mother country" that is still present even more important, it being more than a simple sense of people being Poles, gaining manifestation in actions taken up with a view to Polish ideas being promoted in both the private and public spheres. 